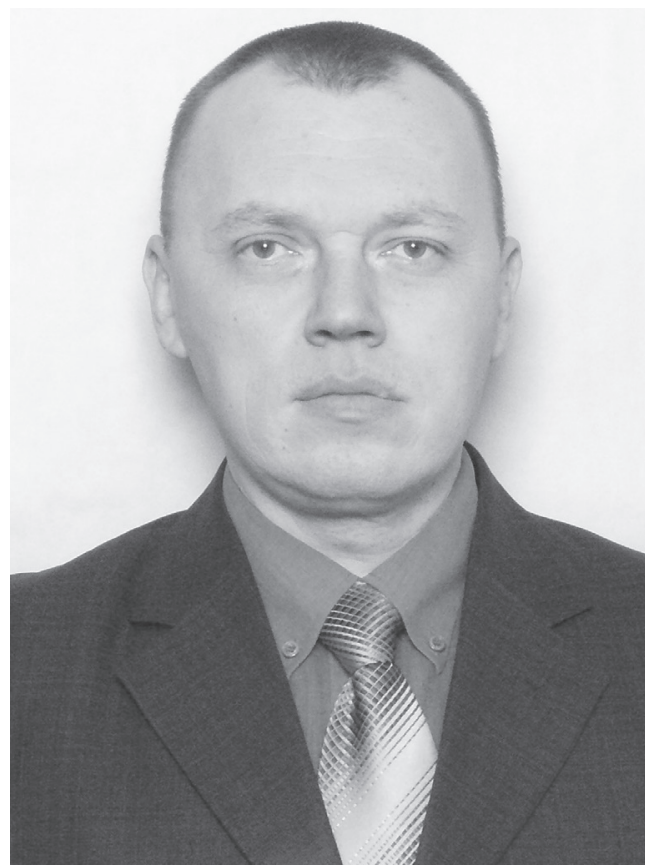

УДК: 351.81

DOI: https://doi.org/10.32689/2617-

2224-2019-5(20)-166-177

Петренко Олександр Миколайович, доктор технічних наук, доцент, дочент кафедри електричного транспорту, Харківський національний університет міського господарства ім. О. М. Бекетова, 61000, м. Харків, вул. Маршала Бажанова, 17, тел.: +38 (093) 66997 47, e-mail: mbubliy@gmail.com

ORCID: 0000-0003-4027-4818

Петренко Александр Николаевич, доктор технических наук, доцент, дочент кафедры электрического транспорта, Харьковский национальный университет городского хозяйства им. А. Н. Бекетова, 61000, г. Харьков, ул. Маршала Бажанова, 17, тел.: +38 (093) 66997 47, e-mail: mbubliy@gmail.com

ORCID: 0000-0003-4027-4818

Petrenko Oleksandr Mykolaiovych,

Doctor of Technical Sciences, Associate Professor, Associate Professor, Department of Electric Transport, Kharkiv National University of Urban Management. OHM. Beketova, 61000, Kharkiv, Str. Marshala Bazhanova, 17,tel.: +38 (093)66997 47, e-mail:mbubliy@gmail.com

ORCID: 0000-0003-4027-4818

\title{
ВПЛИВ СОЦІАЛЬНИХ ФАКТОРІВ НА ВДОСКОНАЛЕННЯ ДЕРЖАВНОГО РЕГУЛЮВАННЯ ГРОМАДСЬКОГО ПАСАЖИРСЬКОГО ТРАНСПОРТУ
}

Анотація. Розглянуто основні фактори, що впливають на діяльність громадського пасажирського автомобільного транспорту. Визначено, що економічну політику у сфері державного регулювання громадського пасажирського транспорту слід розглядати як важливу частину загальної державної економічної і соціальної політики, спрямованої на підвищення якості життя населення. Обгрунтовано, що формування та реалізація економічної політики має пов'язуватися зі створенням дієвих методів, процедур і механізмів соціального та економічного обгрунтування дотацій та встановлення ефективних тарифів на перевезення, спрямованих на збереження і розвиток системи громадського транспорту, узгоджених з планами розвитку, а також ра- 
ціонального управління маршрутами з метою їх оптимізації при використанні сукупності соціально-економічних обмежень.

Доведено, що управління безпекою руху - найважливіша функція держави, яка має ефективно і комплексно реалізовуватися у складі механізмів і процедур управління громадським транспортом. Кількісне зростання автотранспортних засобів в Україні не супроводжується якісними змінами в позитивний бік. Навпаки, зношення автопарку щорічно збільшується, що є причиною підвищеного забруднення навколишнього середовища, аварійності і високих транспортних витрат.

Вибору соціальної за своєю сутністю політики має передувати моделювання 111 основних характеристик і результатів. Отже, такі моделі доцільно створювати і використовувати у практиці державного макроекономічного регулювання. Підвищення ефективності державного регулювання має забезпечуватися податковою регламентацією діяльності підприємств пасажирського транспорту та приватних перевізників через правові механізми, а також рядом організаційних заходів, що забезпечують паспортизацію маршрутів, моніторинг процесів перевезень та їх фінансування з бюджету, вдосконалення механізму та процедур інформаційного забезпечення процесів формування економічної політики та її реалізації.

Ключові слова: державне регулювання, пасажирський автомобільний транспорт, соціальні фактори, тарифна політика, транспортна інфраструктура.

\section{ВЛИЯНИЕ СОЦИАЛЬНЫХ ФАКТОРОВ НА СОВЕРШЕНСТВОВАНИЕ ГОСУДАРСТВЕННОГО РЕГУЛИРОВАНИЯ ОБЩЕСТВЕННОГО ПАССАЖИРСКОГО ТРАНСПОРТА}

Аннотация. Рассмотрены основные факторы, влияющие на деятельность общественного пассажирского автомобильного транспорта. Определено, что экономическую политику в области государственного регулирования общественного пассажирского транспорта следует рассматривать как важную часть общей государственной экономической и социальной политики, направленной на повышение качества жизни населения. Обосновано, что формирование и реализация экономической политики должна быть связана с созданием действенных методов, процедур и механизмов социального и экономического обоснования дотаций и установления эффективных тарифов на перевозку, направленных на сохранение и развитие системы общественного транспорта, согласованных с планами развития, а также рационального управления маршрутами с целью их оптимизации при использовании совокупности социально-экономических ограничений.

Доказано, что управление безопасностью движения - важнейшая функция государства, которая должна эффективно и комплексно реализовываться в составе механизмов и процедур управления общественным транспортом. Количественный рост автотранспортных средств в Украине не 
сопровождается качественными изменениями в положительную сторону. Наоборот, износ автопарка ежегодно увеличивается, что является причиной повышенного загрязнения окружающей среды, аварийности и высоких транспортных расходов.

Выбору социальной по своей сущности политики должно предшествовать моделирование ее основных характеристик и результатов. Поэтому такие модели целесообразно создавать и использовать в практике государственного макроэкономического регулирования. Повышение эффективности государственного регулирования должно быть обеспечено налоговой регламентацией деятельности предприятий пассажирского транспорта и частных перевозчиков через правовые механизмы, а также рядом организационных мероприятий, обеспечивающих паспортизацию маршрутов, мониторинг процессов перевозок и их финансирования из бюджета, совершенствование механизма и процедур информационного обеспечения процессов формирования экономической политики и ее реализации.

Ключевые слова: государственное регулирование, пассажирский автомобильный транспорт, социальные факторы, тарифная политика, транспортная инфраструктура.

\section{THE INFLUENCE OF SOCIAL FACTORS ON IMPROVEMENT OF STATE REGULATION OF PUBLIC PASSENGER TRANSPORT}

Abstract. The article describes the main factors affecting the activities of public passenger road transport. It is determined that the economic policy in the field of state regulation of public passenger transport should be considered as an important part of the General state economic and social policy aimed at improving the quality of life of the population. It is also proposed that the formation and implementation of economic policy should be associated with the creation of effective methods, procedures and mechanisms of social and economic justification of subsidies and the establishment of effective tariffs for transportation aimed at preserving and developing the public transport system, consistent with the development plans, as well as the rational management of routes in order to optimize them using a set of socio-economic constraints.

It is proved that traffic safety management is the most important function of the state, which should be effectively and comprehensively implemented as part of the mechanisms and procedures of public transport management. The quantitative growth of vehicles in Ukraine is not accompanied by qualitative changes in the positive direction. On the contrary, the wear and tear of the vehicle fleet is increasing every year, which is the cause of increased environmental pollution, accidents and high transport costs. As shown above, one of the elements of such a system is the restriction of the age of minibuses allowed on passenger routes.

The choice of social policy should be preceded by the modeling of its main characteristics and results, so it is advisable to create and use such models in the practice of state macroeconomic regulation. Improving the efficiency of state regulation should be provided by the tax regulation of the activities of passenger 
transport enterprises and private carriers through legal mechanisms, as well as a number of organizational measures to ensure the certification of routes, monitoring of transportation processes and their financing from the budget, improving the mechanism and procedures for information support of the processes of economic policy formation and its implementation.

Keywords: state regulation, passenger road transport, social factors, tariff policy, transport infrastructure.

Постановка проблеми. Послуги 3 перевезення пасажирів слід розглядати як послуги міського житлово-комунального господарства та в контексті його загальних проблем. Також можливо відносити послуги пасажирського транспорту до групи соціально-побутових послуг. Тому пошук узагальнень при вирішенні проблем громадського транспорту, з одного боку є важливим для розвитку всього комплексу комунального господарства, а з іншого - слід порівнювати 3 аналізом причин проблем житлово-комунального господарства і знайденими в цій сфері рішеннями.

Можливо виділити ряд проблем, які залишаються невирішеними або можуть знайти своє більш ефективне рішення на базі сучасного розвитку теорії і методів державного регулювання громадського пасажирського транспорту. Проблема гласності цілей і змісту економічної політики, прозорості методів і механізму регулювання залишається частково вирішеною. В цьому плані необхідно не тільки коригувати механізми і процедури регулювання, але і прищепити культуру гласності. Проблема методичного забезпечення економічної політики регулювання громадського пасажирського транспорту. Вона може бути вирішена шляхом створення моделі формування та реалізації економічної політики регулювання громадського пасажирського транспорту, а також розробки нових методів, процедур та механізмів економічної політики регулювання громадського пасажирського транспорту.

Аналіз останніх публікацій за проблематикою. Проблеми державного регулювання громадського пасажирського автомобільного транспорту висвітлені у працях як зарубіжних, так і вітчизняних вчених. Вагомий внесок у дослідження особливостей впливу держави на транспортну систему зробили такі вчені, В. Грабельников [1], В. Джуган [2], О. Дивінець [3], О. Зборовська [3], Д. Ільченко[4], В. Ільчук [5], Н. Ковальчук [7], Г. Корецька. [3], М. Леонов [7], В. Лук'янов [6], А. Новікова [7], Т. Ровенчак [9], В. Степанов [10], О. Шевченко [1], Т. Ященко [7] та ін. Однак, незважаючи на численні дослідження, недостатньо висвітленим залишається вплив соціальних проблем на вдосконалення державного регулювання громадського пасажирського автомобільного транспорту в Україні.

Метою даної статті є визначення впливу соціальних проблем на вдосконалення державного регулювання громадського пасажирського ав- 
томобільного транспорту в Україні та надання пропозицій з удосконалення даного процесу.

Виклад основного матеріалу дослідження. Центральною ланкою 3 формування і реалізації економічної політики по відношенню до громадського пасажирського транспорту є цінова (тарифна) політика, тому ii аналізу та вдосконаленню відводиться важливе місце.

Однією з регіональних проблем є наявність серед споживачів продукції, робіт та послуг значної кількості пільгових категорій споживачів (громадян), визначених законодавством, наявність соціальних маршрутів i відсутність належного відшкодування з бюджетів відповідних рівнів господарюючим суб'єктам не отриманих доходів [7, с. 23]. Особливо гостро ця проблема зачіпає життєзабезпечуючі галузі, як транспорт, зв’язок, енергетика, газопостачання, житлово-комунальне господарство, i негативно відбивається на результатах фінансово-господарської діяльності, також створює ситуацію, коли підприємства природних монополій потрапляють у свого роду “ножиці". 3 одного боку, для компенсації збитків необхідно підвищити дохідну частину, тобто затвердити більш високі тарифи, шляхом завищення планової собівартості послуг, а з іншого - недостатне фінансування і неплатежі споживачів створює дефіцит оборотних коштів, який не дозволяє здійснювати ряд необхідних заходів для ведення нормального виробничо-технологічного процесу на підприємстві.

У процесі децентралізації велика частина функцій по життєзабезпе- ченню переноситься на низові територіальні рівні управління, де на практиці у безпосередній близькості до споживача реалізуються соціальні програми. Процеси проходять у складному правовому середовищі. Житлово-комунальне господарство, що включає в себе проблеми власності на житло, оплату комунальних послуг, системи соціальних гарантій забезпечує економічні і організаційно-правові умови [6, с. 121].

У сформованій ситуації на перший план висувається завдання ефективного управління комплексом міського господарства, який за своєю суттю є витратним, витрати на нього реалізуються в основному через територіальні структури.

За останні роки досягнуто певних результатів щодо реалізації програм економічних реформ. Але, поряд 3 досягненням певних позитивних результатів з'явився ряд невирішених проблем, які перешкоджають подальшому просуванню до ринку і підвищенню рівня життя населення міст. До них відноситься високий рівень монополізації, переважання галузевого підходу у вирішенні проблем територіального управління, відсутність єдиної тарифної політики. В області громадського пасажирського транспорту набагато слабкіше йдуть перетворення, у тому числі в питаннях регулювання.

Саме цими причинами викликана необхідність дослідження проблем державної та муніципальної політики ціноутворення послуг у системі регулювання ринкової економіки.

В даний час в Україні відсутня єдина державна політика, слабка законодавча база у сфері організації 
роботи громадського транспорту, та недосконала методична база формування вартості послуг.

Результати аналізу роботи громадського транспорту в Україні, отримані О. Зборовською, підтверджують неузгоджені діï влади різного рівня, що призводить до таких негативних наслідків як: Зниження якісного рівня громадського транспорту; заміщення автобусів, трамваїв і тролейбусів малогабаритними мікроавтобусами; експлуатація аварійного рухомого складу; зростання державних дотацій [3, с. 25].

Безумовно, одним із важливих напрямків функціонування системи міського пасажирського транспорту, є фінансування програм по відновленню і оновленню рухомого складу громадського транспорту. У більшості міст робота державних i муніципальних автотранспортних підприємств ускладнена старінням основних фондів, зниженням продуктивності праці, збільшенням витрат на утримання старіючого парку [5, с. 129]. Отже, необхідне формування та фінансування програм 3 відновлення та оновлення рухомого складу громадського транспорту на автотранспортних підприємствах.

Як наслідок зазначених причин на зміну підприємствам громадського транспорту приходять власники маршрутних таксі та автобусів, у яких відсутнє необхідне ремонтне та діагностичне обладнання, кваліфікований персонал для проведення профілактичних заходів. Збільшення на ринку послуг з перевезення пасажирів числа суб'єктів малого підприємництва, тягне за собою обмежене впровадження сучасних засобів управління громадськими пасажирськими перевезеннями; недостатню кваліфікацію i низьку дисципліну водіїв автобусів, порушення норм місткості автобусів. Шо посилюється малоефективною системою профілактичної роботи та контролю за дотриманням вимог безпеки дорожнього руху; відсталістю нормативної правової бази у сфері організації маршрутних автобусних перевезень в умовах ринкової економіки.

Одним з шляхів вирішення проблем безпеки руху при експлуатації автобусів, які належать фізичним особам, що здійснюють перевезення пасажирів, є ініціювання їх об’єднання, що дозволяє створювати необхідні умови для дотримання встановлених вимог безпеки.

Тут необхідно відзначити, що приватні власники повинні мати не тільки рівні права, а й рівні обов'язки. В цілому можна говорити про систему умов (вимог), які повинні застосовуватися до власників транспортних засобів (підприємствам та індивідуальним підприємцям, які здійснюють перевезення пасажирів за маршрутами громадського транспорту. Вони повинні дотримуватися і забезпечувати:

- законодавство в частині перевезення пільгових пасажирів;

- встановлені державою маршрути, в тому числі соціальні (збиткові) і тарифи;

- встановлені графіки та інтервали руху транспортних засобів;

- виконання екологічних норм при експлуатації транспорту;

- управління транспортом водіями високої кваліфікацї;

- справний транспорт [1, с. 5]. 
Останні дві вимоги спрямовані на забезпечення необхідного рівня безпеки перевезень, який в Україні відносно низький, про що свідчать дослідження і публікації багатьох відомих вчених, а також дана проблема визначена в Стратегії підвищення рівня безпеки дорожнього руху в Україні на період до 2020 року [8]. Вся сукупність умов безпосередньо пов'язана 3 забезпеченням якості життя населення і є прикладом практичного застосування теорії економічного інтересу.

Основною причиною, що стримує приватних власників маршрутних таксі та автобусів від перевезення пільгових категорій пасажирів та роботи на соціальних маршрутах, є хронічне недофінансування, або відсутність, не отриманих доходів підприємств і приватних власників від перевезення пільговиків.

Проблема фінансового і правового забезпечення територіальної цінової політики в частині формування тарифів та фінансування перевезень пільгових пасажирів, перевезень на соціальних маршрутах проявляється дуже гостро. Це свідчить про необхідність вдосконалення методів формування тарифної політики та методик розрахунку тарифів на пасажирські перевезення.

Економічна політика щодо громадського транспорту повинна розглядатися як частина загальної економічної політики, а послуги з перевезення пасажирів є одним з видів у тому комплексі послуг, які надає соціально орієнтована держава [10, с. 99]. Така політика зачіпає всі рівні державного регулювання, а також мікрорівень, але основний акцент ін- тересів учасників відносин з приводу пасажирських перевезень і прояви, пов’язаних з цим проблем припадає на місцевий рівень. Тому економічна політика у сфері пасажирських перевезень розглядається як важлива частина загальної соціально орієнтованої економічної політики.

Отже, формування та реалізація економічної політики - це сукупність складних, різноманітних за своєю природою (гетерогенних), безперервних або циклічних процесів. Ця сукупність повинна спиратися на дієві моделі, методи, процедури та механізми, кожний або кожна з яких виконує власну роль у загальному гармонізованому процесі.

Соціальна орієнтація такої політики повинна бути загальновизнана з ряду причин, а в економічному аспекті вона повинна забезпечувати відтворення цього виду послуг.

Демократична і соціально орієнтована влада повинна ставити своєю метою підвищення якості життя населення. В цьому плані громадський пасажирський транспорт необхідний широким верствам населення, включаючи ті, які не можуть повною мірою нести витрати по оплаті транспортних послуг і відповідно 3 діючим законодавством актами мають право на пільговий проїзд. Отже, державне регулювання громадського пасажирського транспорту - необхідний елемент соціальних послуг, що надаються державою населенню. На якість життя населення громадський транспорт справляє безпосередній вплив і можливо виділити ряд показників, які слід враховувати при оцінці соціально-економічної ефективності розроблюваної економічної 
політики: зручність маршрутів; вартість проїзду; дотримання графіків та інтервалів руху; безпека пасажирів; можливість користування пільгами, наданими державною владою.

Регулювання маршрутів руху міського транспорту необхідно для того, щоб з цієї сфери послуг не “випадали” віддалені і малонаселені пункти маршрутів, обслуговувати які з чисто комерційних позицій перевізників не вигідно. У зв’ язку з цим реалізується принцип забезпечення приблизно рівного рівня якості життя для жителів у різних частинах муніципального утворення. Отже, регулювання маршрутів не відкидає ідею їх оптимізаціі, але передбачає використання сукупності соціально-економічних (і більшою мірою соціальних) обмежень.

Велика кількість пільговиків - це пенсіонери та інваліди, для яких проїзд у громадському транспорті життєво необхідний за станом здоров’я. Часто такі пасажири використовують транспорт, щоб проїхати 1-2 зупинки саме тому, що їх стан здоров'я не дозволяє обходитися без транспорту [2, с. 78]. Пропозиції по заміні пільг адресними грошовими виплатами у сформованій економічній ситуаціі вирішить безліч проблем.

Регулювання тарифів необхідно в силу невисоких доходів населення i розвиненою спеціалізацією праці, яка призводить більшу частину населення до необхідності щодня по кілька разів переїжджати до місця роботи і назад, добиратися до спеціалізованих підприємств торгівлі, побутового обслуговування, культурно-спортивних установ та організацій, які зазвичай зосереджені в одному або кіль- кох “культурних" центрах міста. В рамках такого регулювання доцільно знати і прогнозувати відтворення послуг, доходи населення, надходження до бюджету і показники процесу старіння населення.

Регулювання тарифів передбачає, з одного боку, соціальне та економічне обгрунтування дотацій на перевезення пільгових пасажирів та перевезення на соціальних маршрутах, а 3 іншого - встановлення ефективних тарифів на перевезення з чисто економічних позицій, у тому числі 3 використанням методів логістики, для того, щоб зберігати і розвивати систему громадського транспорту, узгоджуючи такі дії з планами розвитку муніципальних утворень.

Тарифна (цінова) політика є складовою частиною економічної політики і повинна бути спрямована на вирішення низки завдань:

- забезпечення єдиного економічного простору в регіоні для всіх категорій споживачів і виробників;

- на захист економічних інтересів вітчизняних виробників і постачальників товарів і послуг;

- на захист споживачів від необгрунтовано завищених монопольних цін і тарифів;

- гармонійний облік (узгодження) інтересів підприємств і споживачів послуг шляхом створення і використання відповідного механізму;

- забезпечення самофінансування виробників послуг, організацій що їх постачають;

- створення умов для розвитку конкурентних відносин, стимулювання ресурсозбереження, зниження витрат підприємств на виробництво продукції та послуг, у тому числі 
протидії процесу формування монополій;

- зниження дотацій з бюджету;

- проведення контролю за дотриманням державної дисципліни цін і тарифів усіма підприємствами і організаціями незалежно від форм власності [9, с. 121].

Для здійснення поставлених завдань цінова політика повинна проводитися шляхом:

- послідовної лібералізації цін у галузях, в яких можливий розвиток конкуренції;

- посилення державного регулювання цін і тарифів, в соціально значущих галузях природних локальних монополій.

Особливе місце у ряді проблем регулювання займає проблема оцінки якості регулювання пасажирського транспорту. Система оцінок для пасажирського транспорту ще не розроблена і в цьому плані видається доцільним таку систему оцінок розробити і впровадити у практику управління на місцевому рівні [4, c. 12].

Управління безпекою руху - найважливіша функція держави, яка повинна бути ефективно і комплексно реалізована у складі механізмів і процедур управління громадським транспортом. Кількісне зростання автотранспортних засобів в Україні не супроводжується якісними змінами в позитивну сторону. Навпаки, зношення автопарку щорічно збільшується, що є причиною підвищеного забруднення навколишнього середовища, аварійності і високих транспортних витрат. Як показано вище, один з елементів такої системи - обмеження віку мікроавтобу- сів, що допускаються на пасажирські маршрути.

У регулюванні громадського транспорту велике місце має відводитися податковому регулюванню та перерозподілу податкових надходжень на користь забезпечення зобов'язань держави 3 перевезень пасажирів. Регламентацію діяльності підприємств пасажирського транспорту та приватних перевізників слід здійснювати через правові механізми та паспортизацію маршрутів, а в управлінні та регулюванні використовувати моніторинг перевезень та їх фінансування з бюджету, а також механізм та процедури інформаційного забезпечення процесів формування економічної політики та іiї реалізації.

Центральною ланкою моделі, що дозволяє дослідити основні характеристики та спрогнозувати результати економічної політики регулювання громадського транспорту, повинно стати тарифне моделювання, а загальну оцінку ефективності такої політики доцільно пов'язувати 3 комплексною соціально-економічною оцінкою, що враховує соціальні та економічні показники.

Таким чином, рішення перерахованих проблем може бути знайдене шляхом створення моделі і процедури моделювання основних характеристик і результатів економічної політики державного регулювання громадського пасажирського транспорту, а також комплексу методів та механізмів формування муніципальної економічної політики регулювання громадського пасажирського транспорту та іiі реалізації. Вдосконалення цієї політики може бути забезпечено на основі реалізації 
комплексу відповідних організаційно-економічних заходів, для оцінювання ефективності яких необхідно розробити методику такого оцінювання.

\section{Висновки і перспективи подаль-} ших досліджень. На основі викладеного, може бути запропоновано концептуальний підхід до формування та реалізації державної політики i політики муніципалітетів щодо громадського пасажирського транспорту, що включає наступні основні i принципові моменти:

- економічну політику в області державного регулювання громадського пасажирського транспорту слід розглядати як важливу частину загальної державної економічної i соціальної політики, спрямованої на підвищення якості життя населення. У цьому плані міський громадський транспорт буде представлений як в ринковому, так і в громадському секторах економіки;

- вибору соціальної за своєю сутністю політики має передувати моделювання ㄲï основних характеристик $\mathrm{i}$ результатів, тому такі моделі доцільно створювати і використовувати у практиці державного макроекономічного регулювання;

- формування та реалізація економічної політики має бути пов'язане зі створенням дієвих методів, процедур і механізмів соціального та економічного обгрунтування дотацій та встановлення ефективних тарифів на перевезення, спрямованих на збереження і розвиток системи громадського транспорту, узгоджених з планами розвитку, а також раціонального управління маршрутами 3 метою їх оптимізації при викорис- танні сукупності соціально-економічних обмежень;

- підвищення ефективності державного регулювання повинно бути забезпечено податковою регламентацією діяльності підприємств пасажирського транспорту та приватних перевізників через правові механізми, а також рядом організаційних заходів, що забезпечують паспортизацію маршрутів, моніторинг процесів перевезень та їх фінансування 3 бюджету, вдосконалення механізму та процедур інформаційного забезпечення процесів формування економічної політики та їі реалізації.

\section{СПИСОК ВИКОРИСТАНИХ ДЖЕРЕЛ}

1. Грабельников В. А. Організація регулювання системою міського громадського пасажирського транспорту / В. А. Грабельников, О.В. Шевченко // Вісн. Донецької академії автомобільного транспорту. 2013. № 4. C. 4-9.

2. Джуган В. О. Проблеми юридичної відповідальності за порушення права на безоплатний проїзд автотранспортом загального користування / В. О. Джуган // Держава та регіони. Серія : Право. 2018. № 1 (59). С. $77-$ 82.

3. Зборовсъка О. М. Розвиток підприємств міського електричного транспорту України: проблеми та перспективи / О. М. Зборовська, О. Л. Дивінець // Інвестиції: практика та досвід. 2016. № 24. С. 24-27.

4. Ільченко Д. А. Державне регулювання пасажирського автомобільного транспортного комплексу : автореф. дис. ... канд. екон. наук : 08.00.03/ Д. А. Ільченко; Центр. спілка спожив. т-в України, Львів. торг.-екон. ун-т. Львів, 2017. 20 с. 
5. Ільчук В. П. Комплексний аналіз транспортної мережі міста: системно-аналітичний підхід : монографія / В. П. Ільчук. Харків. С.А.М. 2015. $367 \mathrm{c}$.

6. Лук'янов В. I. Регіональні аспекти державного регулювання розвитку житлово-комунального господарства / В. І. Лук'янов // Соціальна економіка. 2017. № 2. С. 120-124.

7. Новікова А. М. Фінансування громадських послуг з перевезення пасажирів - рівняння на європейський рівень якості / А. М. Новікова, T. М. Ященко, Н. М. Ковальчук, М. А. Леонов // Автошляховик України: наук.-виробничий журн. 2018. № 2. C. 21-27.

8. Про схвалення Стратегії підвищення рівня безпеки дорожнього руху в Україні на період до 2020 року [Електронний ресурс] : Розпорядження Кабінету Міністрів України від 14.06.2017 № 481-р. Режим доступу : https://zakon.rada.gov.ua/ laws/show/481-2017-\%D1\%80

9. Ровенчак T. Г. Тарифна політика один із напрямів реформування галузі ЖКГ / Т. Г. Ровенчак / С Сучасні технології, матеріали і конструкції в будівництві. 2013. № 1. С. 119-124.

10. Степанов В. Ю. Державне регулювання транспортною сферою / В. Ю. Степанов // Вісн. Нац. ун-ту цивільного захисту України. Серія: Державне управління. 2016. Вип. 1. С. 97-103.

\section{REFERENCES}

1. Hrabelnykov V. A., Shevchenko O. V. (2013). Orhanizatsiia rehuliuvannia systemoiu miskoho hromadskoho pasazhyrskoho transportu [Organization of regulation of the system of urban public passenger transport]. Visnyk Donetskoi akademii avtomobilnoho transportu - Bulletin of the Donetsk
Academy of Automobile Transport, 4, 4-9 [in Ukrainian].

2. Dzhuhan V. O. (2018). Problemy yurydychnoi vidpovidalnosti za porushennia prava na bezoplatnyi proizd avtotransportom zahalnoho korystuvannia [Problems of legal liability for violation of the right to free travel by public transport]. Derzhava ta rehiony. Seriia: Pravo - State and regions. Series: Law, 1 (59), 77-82 [in Ukrainian].

3. Zborovska O. M., Dyvinets O. L. (2016). Rozvytok pidpryiemstv miskoho elektrychnoho transportu Ukrainy: problemy ta perspektyvy [Development of enterprises of urban electric transport of Ukraine: problems and perspectives]. Investytsii: praktyka ta dosvid - Investments: practice and experience, 24, 24-27 [in Ukrainian].

4. Ilchenko D. A. (2017). Derzhavne rehuliuvannia pasazhyrskoho avtomobilnoho transportnoho kompleksu [State regulation of the passenger automobile transport complex]. Extended abstract of candidate's thesis. Lviv: Tsentr. spilka spozhyv. t-v Ukrainy, Lviv. torh.ekon. un-t. [in Ukrainian].

5. Ilchuk V. P. (2015). Kompleksnyi analiz transportnoi merezhi mista: systemnoanalitychnyi pidkhid [Complex analysis of the city's transport network: a systemanalytical approach]. Kharkiv. S.A.M. [in Ukrainian].

6. Lukianov V. I. (2017). Rehionalni aspekty derzhavnoho rehuliuvannia rozvytku zhytlovo-komunalnoho hospodarstva [Regional aspects of state regulation of housing and communal services development]. Sotsialna ekonomika - Social economics, 2, 120-124 [in Ukrainian].

7. Novikova A. M., Yashchenko T. M., Kovalchuk N. M., Leonov M. A. (2018). Finansuvannia hromadskykh posluh z perevezennia pasazhyriv - rivniannia na yevropeiskyi riven yakosti [Financing public services on passenger trans- 
portation - the equation to the European level of quality]. Avtoshliakhovyk Ukrainy - Roadster of Ukraine, 2, 2127 [in Ukrainian].

8. Rozporiadzhennia Kabinetu Ministriv Ukrainy "Pro skhvalennia Stratehii pidvyshchennia rivnia bezpeky dorozhnoho rukhu v Ukraini na period do 2020 roku" : vid 14 chervnia 2017, № 481-r [Order of the Cabinet of Ministers of Ukraine "On the approval of the Strategy for improving the level of road safety in Ukraine up to 2020” from June 14 2017, № 481-p]. zakon.rada.gov.ua. Retrieved from https://zakon.rada.gov.ua/laws / show/481-2017-\%D1\%80 [in Ukrainian].
9. Rovenchak T. H. (2013). Taryfna polityka - odyn iz napriamiv reformuvannia haluzi ZhKH [Tariff policy - one of the areas of housing sector reform]. Suchasni tekhnolohii, materialy $i$ konstruktsii v budivnytstoi - Modern technologies, materials and constructions in construction, 1, 119-124 [in Ukrainian].

10. Stepanov V. Yu. (2016). Derzhavne rehuliuvannia transportnoiu sferoiu [State regulation of transport sphere]. Visnyk Natsionalnoho universytetu tsyvilnoho zakhystu Ukrainy. Seriia: Derzhavne upravlinnia - Bulletin of the National University of Civil Protection of Ukraine. Series: Public Administration, 1, 97-103 [in Ukrainian]. 